\title{
ALPHA-GLUCOSIDASE INHIBITING ACTIVITY FROM THE MOST ACTIVE FRACTION OF CALOPHYLLUM TOMENTOSUM, WIGHT LEAVES
}

\author{
BERNA ELYA*, NURAINI PUSPITASARI, FASYA HADAINA MAHARANI
}

Department of Pharmacy, Faculty of Pharmacy, Universitas Indonesia, Depok, Indonesia. Email: berna.elya@farmasi.ui.ac.id

Received: 21 April 2017, Revised and Accepted: 13 July 2017

\section{ABSTRACT}

Objective: The purpose of this study was to obtain the inhibitory concentration, $50 \%$ value from the most active fraction of methanolic extract of leaf Calophyllum tomentosum, Wight, and to identify the group of compounds contained in the most active fraction.

Methods: The methanol extract was fractionated using the silica gel static phase, the $n$-hexane motion phase, ethyl acetate, and methanol enhanced by its polarity.

Results: There were nine selected fractions tested in inhibitory activity using an enzyme activity inhibitory assay.

Conclusions: The results showed the inhibition by the most active fraction is $51.288 \mu \mathrm{g} / \mathrm{mL}$; this fraction contains of flavonoid, saponin, and terpenoid.

Keywords: Diabetes mellitus, Calophyllum tomentosum Wight., Fractionation, $\alpha$-glucosidase, Enzyme inhibitory assay.

(C) 2017 The Authors. Publishedby Innovare AcademicSciences PvtLtd. This is an open access article under the CC BY license (http://creativecommons. org/licenses/by/4. 0/) DOI: http://dx.doi.org/10.22159/ajpcr.2017.v10s5.23101

\section{INTRODUCTION}

Diabetes mellitus is a group of metabolic disease disorders characterized by hyperglycemia associated with abnormalities in carbohydrate, fat, and protein metabolism, and which results in chronic complications, including microvascular, macrovascular, and neuropathic disorders [1]. According to International Diabetes Federation data, there are 415 million people in the world with diabetes and is expected in 2040 to afflict 642 million people with age 20-79 years. Indonesia alone has a population of 10 million people affected by diabetes and this number is expected to increase to 16.2 million people by the year 2040 [2]. Therapies that can be given for diabetics are pharmacological and non-pharmacological. The first therapy given was non-pharmacological therapy in the form of diet and exercise. Pharmacological therapies in the form of oral hypoglycemic drugs consist of drugs that triggered insulin secretion of sulfonylurea and glinide groups; insulin sensitivity enhancers (biguanide and thiazolidindione), and $\alpha$-glucosidase inhibitors [3].

One of the pharmacological therapies to treat diabetes is to delay the absorption of glucose through inhibition of enzymes, such as alphaglucosidase, in the digestive organs [4]. Oral hypoglycemic drugs inhibiting $\alpha$-glucosidase will reduce post-prandial glucose concentration to $40-50 \mathrm{mg} / \mathrm{dl}$ with unchanged fasting blood sugar level. This means lowering post-prandial glucose levels by about $10 \%$. The $\alpha$-glucosidase inhibitors work competitively against maltase, isomaltase, sucrase, and glucoamylase in the small intestine and delay the breakdown of sucrose and complex carbohydrates [1]. Allopathic drugs have not shown any significant effect for the treatment of the disease, so the focus has been turned toward a traditional system of medicine [5]. Currently, herbal medicine is still widely used in Indonesia. The tendency in society toward a "back to nature" lifestyle makes herbal medicine a choice for maintaining health. In Indonesia, according to the national survey of $2000,15.6 \%$ of the population used traditional medicines for selfmedication, and the number increased to $31.7 \%$ in 2001 [6]. These data can be used as a reference in the basic framework of herbal medicine development in Indonesia. This basic framework includes a synthesis of nutritious compounds from medicinal plants. An example is the acarbose acting as an $\alpha$-glucosidase inhibitor isolated from Actinoplanas utahences in 1990 [7].
Among the plants that are potentially $\alpha$-glucosidase inhibitors is the Calophyllum plant that is from the Clusiaceae family [8]. Calophyllum generally has xanthone compounds that act as antioxidants, which inhibit oxidation in metabolic processes [9] and play a role in inhibiting the production of nitric oxide and 15-LOX in anti-inflammatory activity [10]. This research studied the methanol Calophyllum tomentosum, Wight extract that has potential as an antidiabetic treatment. Previous research has suggested that methanol extract from the $C$. tomentosum, Wight leaf has $\alpha$-glucosidase inhibitory activity with inhibitory concentration $50 \%\left(\mathrm{IC}_{50}\right.$ ) of $89.90 \mu \mathrm{g} / \mathrm{mL}$ [11]. Therefore, in this study, fractionation was done using column chromatography to obtain the most active fraction capable of inhibiting $\alpha$-glucosidase activity.

\section{MATERIALS AND METHODS}

\section{Material}

Methanol extract of $C$. tomentosum leaf obtained from the Laboratory of Phytochemistry and Pharmacognosy, Faculty of Pharmacy, Universitas Indonesia, $\alpha$-glucosidase from Saccharomyces cerevisae (Sigma Aldrich), p-nitrofenil-D-glukopiranosida (PNPG) (Sigma Aldrich), bovine serum albumin (Sigma Aldrich), potassium dihydrogen phosphate (Merck), sodium carbonate (Merck), sodium hydroxide (Merck), hydrochloric acid (Merck), acetic anhydride (Merck), sulfuric acid (Merck), silica gel 60 (0.063-0.200 mm) for column chromatography (Merck), acarbose (Dexa Medica), and quercetin (sigma Aldrich).

\section{Tools}

Microplate reader (Multiscan FC Thermofisher Scientific; Biotek Elx808), pH meter (Eutech Instruments), and rotary vacuum evaporator (Buchi).

\section{Fractionation}

Methanol C. tomentosum, Wight extract iswas fractionated by accelerated column chromatography with a silica gel static phase and a motion phase of $n$-hexane, ethyl acetate, and methanol with an increase of $10 \%$ polarity. The collected fraction was accommodated in a $100 \mathrm{~mL}$ glass vial. The fractions obtained were identified using thin layer chromatography (TLC). Fractions with similar elution results were 
combined into one fraction. TLC identification was performed using ultraviolet (UV) light with wavelengths of 254 and $366 \mathrm{~nm}$.

\section{Alpha-glucosidase inhibiting activity}

Each reactant solution consisted of $36 \mu \mathrm{L}$ of phosphate buffer solution and $30 \mu \mathrm{L}$ of sample solution at various concentrations $(250,350,500$, 650 , and $800 \mu \mathrm{g} / \mathrm{mL}$ ), with final concentrations of 37.5, 52.5, 75.0, 97.5, and $120 \mu \mathrm{g} / \mathrm{mL}$. For the PNPG assay, $17 \mu \mathrm{L}$ of substrate with a concentration of $3.0 \mathrm{mM}$ were placed into the microplate, and then, incubated at $37^{\circ} \mathrm{C}$ for 5 minutes. Afterward, $17 \mu \mathrm{L} \alpha$-glucosidase solutions with a concentration of $0.025 \mathrm{U} / \mathrm{mL}$ was added to each well until a total volume of $100 \mu \mathrm{L}$ was obtained. The mixture was incubated for 15 minutes for a complete hydrolysis reaction. After 15 minutes, the reaction was stopped by adding $100 \mu \mathrm{L}$ of $200 \mathrm{mM}$ sodium carbonate $\left(\mathrm{Na}_{2} \mathrm{CO}_{3}\right)$ solution, and the absorbance was measured at a wavelength of $405 \mathrm{~nm}$ using a microplate reader. Each test was repeated three times.

After obtaining the data from each test, the data were processed using the following steps:

a. Determining the average absorbance of blanks, blank controls, sample controls, and samples

b. Calculating the absorbance difference between the blank and the blank control to obtain the blank absorption $\left(A_{1}\right)$ and the absorbance difference between the sample and the sample control to produce an absorbance value referred to as $\mathrm{A}$

c. Determine the percentage of inhibition each test sample by the formula:

$$
\% \text { inhibition }=\frac{\begin{array}{l}
\text { Absorbancecontrol }- \\
\text { Absorbancesample }
\end{array}}{\text { Absorbancecontrol }} \times 100
$$

This experiment used five variations of sample concentration. The percentage of inhibition obtained in each sample was processed in graphical form and compared with percent inhibition of the acarbose as its positive control.

IC $_{50}$ is the inhibitory concentration of the extract on the activity of $\alpha$-glucosidase based on experimental conditions. IC $_{50}$ can be measured using the linear regression equation $y=a+b x$, where $y$ is the percent of inhibition and $\mathrm{x}$ is the sample concentration, so that the equation is:

$$
\mathrm{IC}_{50}=\frac{50-\mathrm{a}}{\mathrm{b}}
$$

\section{Phytochemical filtering}

Phytochemical filtering is performed on the most active fraction which has the best inhibition against $\alpha$-glucosidase activity. A total of $\pm 10 \mathrm{mg}$ fraction was dissolved in $1 \mathrm{~mL}$ of solvent, and the fraction solution was then placed in a bottle for the TLC plate. The elution was performed using the appropriate motion phase to be identified [10]. After elution, the plates were dried at room temperature, and then, analyzed using UVvisible spectrophotometry at 254 and $366 \mathrm{~nm}$ wavelengths. The spray reagents used for detection were Dragendorff's reagent (for alkaloids), $\mathrm{AlCl}_{3}$ (for flavonoids), vanillin-sulfuric acid (for terpenoids), $\mathrm{FeCl}_{3}$ (tannins), sulfuric acid (saponins), and 8\% KOH (anthraquinones) [12].

\section{RESULTS AND DISCUSSION}

The result showed 20 fractions (A-T), and selected fractions (L-T) that had weights of more than $100 \mathrm{mg}$. The complete data are presented in Table 1. Fractionation was performed using a silica gel static phase and a solvent with multilevel polarity that is $n$-hexane, ethyl acetate, and methanol.

The selected fractions, inhibition of $\alpha$-glucosidase activities were performed to find the most active fraction that has the ability to inhibit $\alpha$-glucosidase activity. Each tested sample was prepared in five different concentrations $(37.5,52.5,75.0,97.5$, and $120 \mu \mathrm{g} / \mathrm{mL})$ with the same substrate and enzyme volumes. The PNPG substrate used during the study had a concentration of $3.0 \mathrm{mM}$, while the enzymes used in the study had a concentration of $0.025 \mathrm{U} / \mathrm{mL}$. This selection of substrate and enzyme concentrations was based on optimization of the substrate concentration, which had been done previously.

Determination of the substrate concentration was done to know in which substrate concentration the enzymes would work optimally. The test was conducted based on previous research using an enzyme activity of $0.15 \mathrm{U} / \mathrm{mL}$, and for which the substrate concentration was $5.0 \mathrm{mM}$. However, this treatment resulted in absorption above 3 ,

Table 1: Weight of chromatography column fraction results

\begin{tabular}{lll}
\hline Fraction & Vial number & Fraction weight $\mathbf{( m g )}$ \\
\hline A & 14 & 8.3 \\
B & $18-20$ & 26.7 \\
C & $23-25$ & 38.5 \\
D & $27-28$ & 27.3 \\
E & $29-30$ & 29.0 \\
F & $31-32$ & 55.3 \\
G & $33-35$ & 52.0 \\
H & $37-40$ & 70.4 \\
I & $43-45$ & 44.4 \\
J & $45-47$ & 20.9 \\
K & $48-49$ & 506 \\
L & $54-55$ & 533.2 \\
M & $56-57$ & 852.5 \\
N & $58-59$ & 754.6 \\
O & $60-61$ & 1102.3 \\
P & $62-65$ & 2689.6 \\
Q & $65-66$ & 1000.4 \\
R & $67-69$ & 1786.7 \\
S & $70-75$ & 683.2 \\
T & $76-79$ & 1095.4 \\
\hline
\end{tabular}

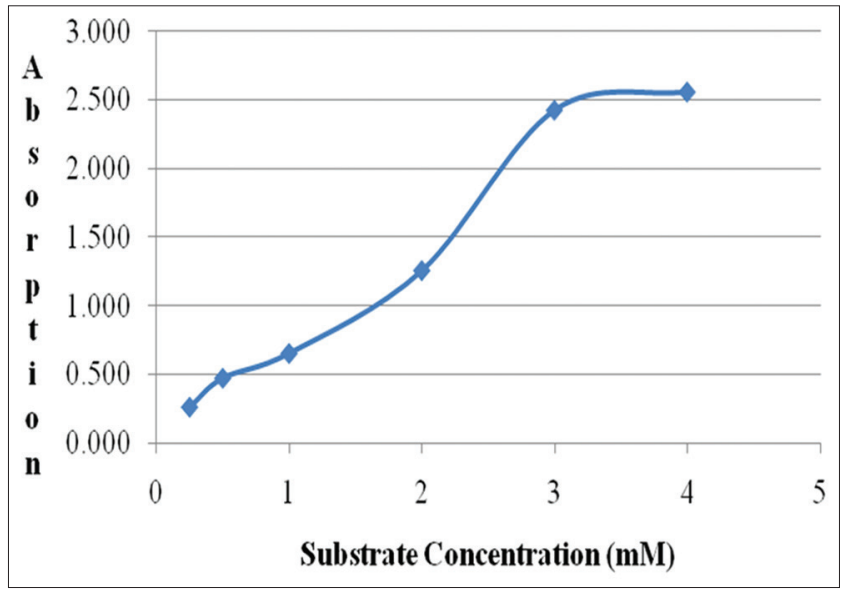

Fig. 1: Optimization graph of p-nitrofenil-D-glukopiranosida substrate concentration with enzyme activity of $0.15 \mathrm{U} / \mathrm{mL}$

Table 2: Result of optimization absorption of enzyme concentration

\begin{tabular}{ll}
\hline Enzyme activity $(\mathbf{U} / \mathbf{m L})$ & Absorption \\
\hline 0.025 & 0.446 \\
0.05 & 0.946 \\
0.075 & 1.244 \\
0.1 & 1.435 \\
0.125 & 1.660 \\
0.15 & 1.767 \\
\hline
\end{tabular}


which was far from the absorption range of 0.2-0.8. Therefore, it was necessary to reoptimize the substrate concentration.

Reoptimization of substrate concentration was done using a concentration below $5.0 \mathrm{mM}$ to obtain absorption in the range of $0.2-0.8$. In this test, five variations of concentration $(0.25,0.5,1.0,2.0,3.0$, and $4.0 \mathrm{mM}$ ) were used, and the curve as presented in Fig. 1. Based on the graph above, for the concentration range of $0.25-3.0 \mathrm{mM}$ the resulting absorption increases as the substrate concentration increases, then at a concentration of $3.0 \mathrm{mM}$ the absorption begins to remain constant, indicating that the enzyme has become saturated by the substrate, so that an increase in substrate concentration will not raise absorption significantly. This is because the all of the active sites of the enzymes have become occupied by the substrates.

The curve above shows that an optimum concentration of $3.0 \mathrm{mM}$ of substrate produced an absorption of about 2429, which is well above the range of $0.2-0.8$, so that enzyme activity needs to be lowered further

\section{Table 3: Test results of phytochemical filtering}

\begin{tabular}{ll}
\hline Chemical contains & Q fraction \\
\hline Alkaloids & - \\
Flavonoids & + \\
Glycosides & - \\
Saponins & + \\
Terpenoids & + \\
Tannins & - \\
Anthraquinones & - \\
\hline
\end{tabular}

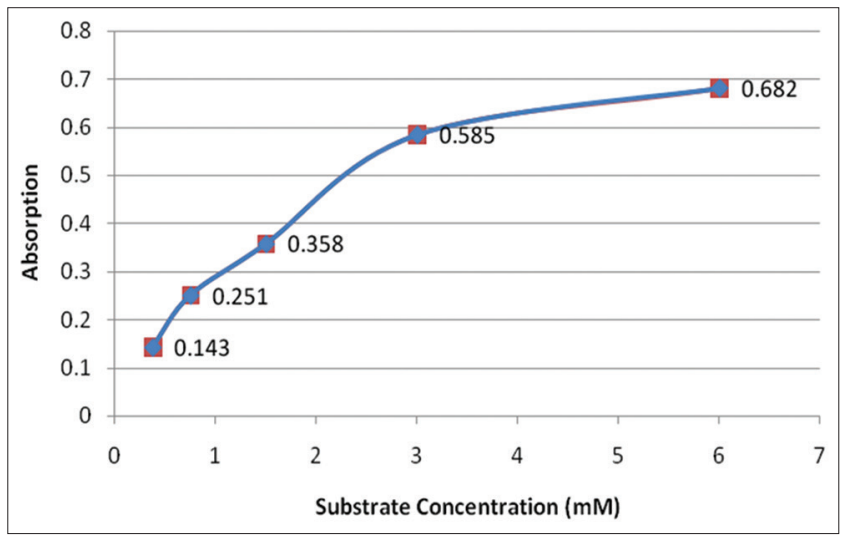

Fig. 2: Optimization graph of p-nitrofenil-D-glukopiranosida substrate concentration with $\alpha$-glucosidase activity of $0.025 \mathrm{U} / \mathrm{mL}$

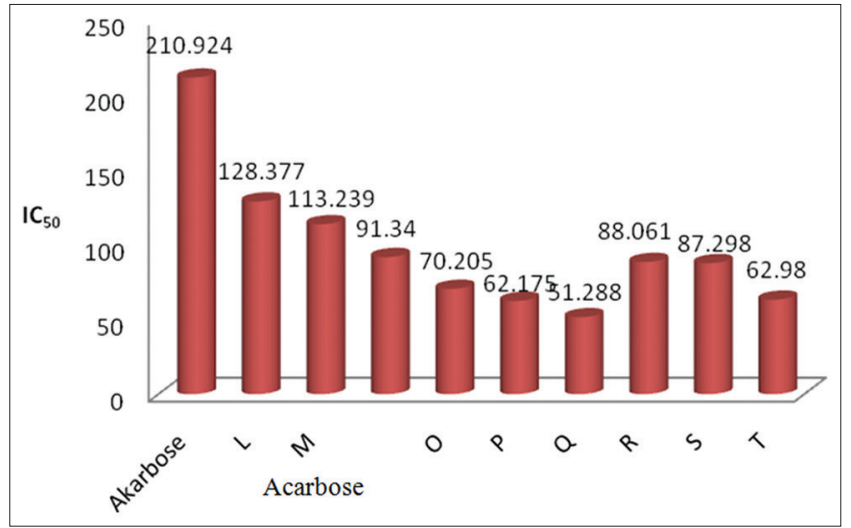

Fig. 3: Inhibitory concentration $50 \%$ acarbose profile and each fraction to obtain ideal absorption. At this stage, six variations of enzyme activity were used below $0.15 \mathrm{U} / \mathrm{mL}$ : 0.025, 0.050, 0.075, 0.100, 0.125 , and $0.150 \mathrm{U} / \mathrm{mL}$. This test produced the resulting absorption values presented in Table 2 . Based on the resulting absorption values, the enzyme concentration used was $0.025 \mathrm{U} / \mathrm{mL}$. Subsequently, the substrate concentration was optimized again using an enzyme with the activity of $0.025 \mathrm{U} / \mathrm{mL}$ and various substrate concentrations: 0.375 , $0.750,1.50,3.00$, and $6.00 \mathrm{mM}$. The PNPG substrate optimization curve can be seen in Fig. 2. The subsequent test used an enzyme activity of $0.025 \mathrm{U} / \mathrm{mL}$ and PNPG substrate concentration of $3.0 \mathrm{mM}$. The most active fraction is represented by $\mathrm{Q}$ fraction, which has the lowest $\mathrm{IC}_{50}$ value $(51.228 \mu \mathrm{g} / \mathrm{mL})$ compared to the other fractions and acarbose profile (Fig. 3).

The Q fraction was tested to identifying of phytochemical compound using phytochemical screening. There uses TLC method. It screened of flavonoids, glycosides, terpenoids, saponins, tannins, and anthraquinones. Flavonoids are polyphenolic compounds that have beneficial effect on glucose and lipid homeostasis, theses compound have been proven to enhance insulin secretion, improve hyperglycemia, reduce insulin resistance, and increasing glucose uptake in skeletal muscle, and white adipose tissue [4]. The results of the phytochemical screening showed in Table 3.

\section{CONCLUSION}

The present work can be concluded that the most active fraction from methanol extract of $C$. tomentosum Wight. leaves are $\mathrm{Q}$ fraction with $\mathrm{IC}_{50}$ value is $51.288 \mu \mathrm{g} / \mathrm{mL}$. It is contained of flavonoids, saponins, and tannins. For further research, it is needed to be isolated the most active fraction to find the specific compounds which has $\alpha$-glucosidase inhibitory activity. In addition, it is necessary to test in vivo using experimental animals for the development of potential alternative drugs as antidiabetic agents.

\section{REFERENCES}

1. Dipiro JT, Talbert LR, Yee CG, Matzke RG, Wells GB, Posey LM. Pharmacotherapy: A Pathophysiologic Approach. $7^{\text {th }}$ ed. New York: The McGraw-Hill Companies, Inc.; 2008.

2. International Diabetes Federation. IDF Diabetes Atlas. $7^{\text {th }}$ ed. Brussels, Belgium: International Diabetes Federation; 2015.

3. Granata A, Insalaco M, Di Nicolò P, Scarfia VR, Russo L, D'anna G, et al. Oral hypoglycemic drugs in chronic kidney disease: Which limitations in the clinical setting. G Ital Nefrol 2014;31. pii: Gin/31.1.7.

4. Hasimun P, Adnyana IK, Valentina R, Lisnasari E. Potential alphaglucosidase inhibitor from selected Zingiberaceae family. Asian J Pharm Clin Res 2016;9(1):164-7.

5. Lakshmi SM, Rani KS, Reddy TU. A review on diabetes mellitus and the herbal plants used for its treatment. Asian J Pharm Clin Res 2012;5(4):15-21.

6. Dewoto HR. Pengembangan obat tradisional Indonesia menjadi fitofarmaka. Majalah Kedokt Indones 2007;57:205-11.

7. Ghani U. Re-exploring promising a-glucosidase inhibitors for potential development into oral anti-diabetic drugs: Finding needle in the haystack. Eur J Med Chem 2015;103:133-62.

8. Elya B, Basah K, Mun'im A, Yuliastuti W, Bangun A, Septiana EK. Screening of a-glucosidase inhibitory activity from some plants of Apocynaceae, Clusiaceae, Euphorbiaceae, and Rubiaceae. J Biomed Biotechnol 2012;2012:281078.

9. Lim TK. Edible Medicinal and Non-Medicinal Plants, Fruits. Vol. 2. London: Springer; 2012.

10. Paul J, Meli A, Fouotsa H, Djama C, Ephrem A, Sewald N, et al. Phytochemistry letters anti-inflammatory activity of benzophenone and xanthone derivatives isolated from Garcinia (Clusiaceae) species. Phytochem Lett 2015;14:153-8.

11. Kristiyanti. Uji potensi antidiabetes dengan metode penghambatan aktivitas alfa-amilase dan alfa-glukosdase dari daun Calophyllum tomentosum wight. Depok: Universitas Indonesia; 2015.

12. Wagner H, Bladt S, Zgainski EM. Plant Drug Analysis. Munchen: Springer; 1984. 